\section{Farmers' Perspectives on Challenges and Opportunities Associated with Using High Tunnels for Specialty Crops}

\author{
Analena B. Bruce ${ }^{1}$, Elizabeth T. Maynard ${ }^{2}$, and James R. Farmer ${ }^{3}$
}

ADDITIONAL INDEX WORDs. hoophouse, season extension, plasticulture, protected agriculture, case study

SUMMARY. High tunnels are an increasingly popular part of the infrastructure among small and diversified farms that market their products directly to consumers. In addition to extending the growing season, research has strongly indicated that high tunnels can increase yield, enhance shelf life, and improve the quality of crops grown. The objective of this study was to gain a better understanding, from the perspective of farmers, of the challenges and opportunities associated with adopting high tunnels for specialty crops in Indiana. We collected information through a case study that included questionnaires and in-depth interviews with 20 farmers. We found that the additional labor and time requirements of high tunnel production, the increased complexity of high tunnel production, soil fertility, and disease management, and limited winter markets posed the greatest challenges. The ability to differentiate their products based on higher quality and longer shelf life, the ability to obtain a premium price, the ability to have a source of income during the off-season, and the ability to produce complementary crops were the most important opportunities for using high tunnels. This research implied ways to expand opportunities and reduce barriers to maximizing the potential of high tunnels. Understanding the human dimensions of managing high tunnels is important for providing extension educators and Natural Resources Conservation Service field staff with better knowledge of the common difficulties and benefits of this technology so they are better able to advise farmers considering investing in a high tunnel. A focus on the human dimensions is also helpful for identifying research priorities to evaluate new approaches to decreasing problems and increasing benefits. Consequently, this study provided an in-depth understanding of farm-level challenges associated with high tunnel adoption to improve future research in diverse fields.

$\mathrm{T}$ The global production of specialty crops, such as high-value vegetables, has been transformed by the use of high tunnels to moderate extreme weather events and climate conditions, allow for extended growing seasons, and offer protection against some insects and pests (Lamont, 2009). These plasticcovered structures are built directly over the soil, and plants are typically grown directly in the soil. They are passively heated by solar energy, but they do not have fully automated venting, cooling, or heating systems, thereby providing many of the benefits of a greenhouse but at a much lower cost (Carey et al., 2009; Lamont, 2009). This technology became popular in many countries in the 1970s, and a 2009 survey of high tunnel use worldwide found that this technology was most widely used in China, where high tunnels covered 360,000 ha, followed by Spain with 55,000 ha and Japan with 52,500 ha (Lamont, 2009). At that time, high tunnels were only in use on 5000 ha in the United States (Lamont, 2009). However, high tunnels are increasingly being used for specialty crop production in the United States, partly because of a nationwide high tunnel support effort launched as Farmer, Know Your Food initiative of the U.S. Department of Agriculture (USDA) in 2009 (Starmer, 2014; U.S. Department of Agriculture, n.d.). The pilot program was successful and established as the High Tunnel Initiative (HTI) through the Natural Resources Conservation Service (NRCS) as part of the Environmental Quality Incentives Program (EQIP) a pilot program with the Know Your
(NRCS, 2015). This program supported the construction of more than 13,000 high tunnels on farms in all 50 United States (National Sustainable Agriculture Coalition, 2014). Although not initiated in Indiana until 2012 , the response was "overwhelming," and 169 tunnels were constructed between 2012 and 2014 (A. Heichelbech, personal communication).

Research trials have shown great promise for high tunnels to make a pivotal difference in farmers' abilities to increase their production by increasing crop yield and extending the growing season (Belasco et al., 2013; Conner et al., 2010; Orzolek, 2013). However, that promise depends, in part, on farmers' success with integrating high tunnel production with their farms. Conner et al. (2010) and Waldman et al. (2012) reported that although high tunnel use offers potential benefits, it also requires specialized knowledge and experience for successful implementation. In their study of 12 beginning farmers in Michigan who adopted high tunnels, the researchers found mixed results in terms of success with increasing profitability and meeting management goals (Conner et al., 2010; Waldman et al., 2012). For instance, the income from the high tunnels increased initially, but it plummeted by the third year of the study due to cost and labor inefficiencies (Waldman et al., 2012). Overall, farmers' success with generating income from their high tunnels was limited by management factors such as timing when to invest more labor and allocating more time and labor to managing the high tunnel (Waldman et al., 2012). Specifically, they found that the most profitable farmers invested their labor during the spring and fall months, rather than the summer months, and that keeping the high tunnel full was important for success (Waldman et al., 2012). The availability of off-season markets that support the season extension and year-round production is related to

\begin{tabular}{lllc}
\hline $\begin{array}{l}\text { Units } \\
\begin{array}{l}\text { To convert U.S. to SI, } \\
\text { multiply by }\end{array}\end{array}$ & U.S. unit & SI unit & $\begin{array}{l}\text { To convert SI to U.S., } \\
\text { multiply by }\end{array}$ \\
\hline 0.4047 & $\mathrm{acre}(\mathrm{s})$ & $\mathrm{ha}$ & 2.4711 \\
0.0929 & $\mathrm{ft}^{2}$ & $\mathrm{~m}^{2}$ & 10.7639 \\
0.4536 & $\mathrm{lb}$ & $\mathrm{kg}$ & 2.2046 \\
4.8824 & $\mathrm{lb} / \mathrm{ft}^{2}$ & $\mathrm{~kg} \cdot \mathrm{m}^{-2}$ & 0.2048
\end{tabular}


the timing of labor investment. The study performed in Michigan found that few areas had year-round markets, and those that did were not welltrafficked in the early spring and late fall, when it would be most profitable for farmers to produce crops in their high tunnels (Waldman et al., 2012). A survey of 81 growers using high tunnels in the U.S. Great Plains found that labor was the limiting factor for farmers who wished to increase their high tunnel production (Knewtson et al., 2010). Small but intensive studies like these create questions about how effectively specialty crop farmers are using high tunnels.

Previous studies identified a range of outcomes and the importance of labor as a limiting factor, but they did not elucidate the farmers' experiences that led to their conclusions. There is a need for qualitative research focused on the human dimensions of high tunnel management because few studies have measured farmers' perceptions of the factors that affect the outcomes and impacts of growing specialty crops in high tunnels. Understanding and addressing critical limiting factors are

Received for publication 21 Dec. 2018. Accepted for publication 5 Mar. 2019.

Published online 7 May 2019

This material is based on work supported by the U.S. Department of Agriculture and the Indiana State Department of Agriculture under Award Number 15SCBGIN0032. This report was prepared as an account of work sponsored by an agency of the U.S. Government and the State of Indiana. Neither the U.S. Government nor State of Indiana, nor any agency thereof, nor any of their employees, makes any warranty, express or implied, or assumes any legal liability or responsibility for the accuracy, completeness, or usefulness of any information, apparatus, product, or process disclosed, or represents that its use would not infringe privately owned rights. Reference herein to any specific commercial product, process, or service by trade name, trademark, manufacturer, or otherwise does not necessarily constitute or imply its endorsement, recommendation, or favoring by the U.S. Government, the State of Indiana, or any agency thereof. The views and opinions of authors expressed herein do not necessarily state or reflect those of the U.S. Government, the State of Indiana or any agency thereof.

${ }^{1}$ The Ostrom Workshop, Indiana University, $513 \mathrm{~N}$. Park Avenue, Bloomington, IN 47408

${ }^{2}$ Department of Horticulture and Landscape Architecture, Purdue University, 625 Agriculture Mall Drive, West Lafayette, IN 47907

${ }^{3}$ School of Public \& Environmental Affairs, Indiana University, 513 N. Park Avenue, Bloomington, IN 47408

${ }^{4}$ Corresponding author. E-mail: jafarmer@indiana. edu

This is an open access article distributed under the CC BY-NC-ND license (https://creativecommons.org/ licenses/by-nc-nd/4.0/).

https://doi.org/10.21273/HORTTECH04258-18 important to get the most out of public and private investments in high tunnel technology. In a recent survey of farmers using high tunnels in Indiana, it was reported that this technology increased the quality, yield, and shelf life of their specialty crops and improved the economic stability of the farms (Bruce et al., 2017). However, the survey did not provide detailed information about the constraints and benefits. Therefore, we conducted interviews with 20 farmers to gain a more in-depth understanding of farmers' perceptions of the farmlevel impacts of growing specialty crops in high tunnels and analyzed these interviews.

\section{Methods}

Our study presents findings from a qualitative case study that was designed as a follow-up to a survey of farmers using high tunnels across Indiana. The goal was to gain an understanding of the farm-level challenges and opportunities experienced after adopting high tunnels. Qualitative research methods are valuable for learning about actual experiences and understanding farmers' perceptions of specific situations (Miles and Huberman, 1994). This approach is also valuable for obtaining a better understanding and explanation of quantitative data, such as that contained in a survey (Miles and Huberman, 1994). A qualitative approach was ideal for this study because it provided a richer picture of farmers' experiences with high tunnels and a better understanding of specific challenges and opportunities identified in previous survey-based research.

The case study included in-depth interviews with 20 farmers using high tunnels in south and central Indiana. These farmers were identified by their participation in the survey and were part of a subset of 59 out of the complete sample of 103 survey respondents who provided their phone numbers and indicated willingness to participate in follow-up farm visits. From the subset of 59 volunteers, 20 farmers were selected for the case study; they were offered a gift card of $\$ 200$ as an incentive for their participation. Farmers were selected strategically to represent a range of approaches to using high tunnels and a variety of farm types, including full-time and part-time farmers, beginning and experienced farmers, those producing specialty crops, commodity crops, livestock, or some combination of these, and those operating small, midscale, and large farms. Out of the 20 farms we visited, 3 had automated ventilation systems in their high tunnels and 6 had a unit heater or wood stove that they used occasionally to boost plant growth. A project researcher visited each of the 20 farms one time between 2016 and 2017 and spent half a day at each farm. Case study data collection included an interview lasting an average of 40-90 min that included oral responses to a questionnaire garnering information about how they managed their high tunnels and a tour of the high tunnel.

Interviews included a series of questions about the history of the farm, farming experience, production methods, and marketing strategy used for their high tunnel products. To gain a better understand of why farmers do not always successfully increase their farm's profitability with high tunnels or meet management goals, we asked about the learning curve that farmers experienced when using their high tunnels and about their experience integrating high tunnels with the rest of the farm. We also asked what their greatest challenges and opportunities were, and what specific opportunities and challenges they experienced regarding season extension. This was of particular interest because in previous studies, researchers found that an emphasis on season extension was linked to increased profitability and success. To gain a better understanding of the divergent experience and success of farmers using high tunnels reported in previous studies, we asked farmers what they thought had made them successful, both in terms of the strategies they used and the support that they received. In addition, we asked about the number of hours they worked on the farm and how they recruited and managed their labor force.

The interviews were transcribed verbatim and coded and analyzed with NVivo qualitative analysis software (version 11; QSR International, Burlington, MA). The coding process was completed by the researcher who conducted the on-farm interviews and included an initial read to identify general themes, a second reading and 
initial coding for important themes, and a third reading and coding phase that refined the initial coding categories into general categories and subcategories based on emerging themes (Creswell and Poth, 2017). This coding process assured internal consistency for coding by one researcher (Miles and Huberman, 1994). The general categories and subcategories related to opportunities and challenges identified by farmers are presented here and are summarized in Table 1.

\section{Results and discussion Challenges}

MANAGING THE TIME AND LABOR REQUIREMENTS OF HIGH TUNNEL PRODUCTION. One of the most commonly mentioned challenges described by farmers was the difficulty with keeping up with the added time and labor required to manage their high tunnels. Farmers explained that high tunnel production increased the complexity of farm management; therefore, it required more labor and attention. The research team noted that one reason why high tunnel crops are more labor-intensive for farmers is because high tunnel planting and harvesting schedules are substantially different from what they are familiar with and require schedules that are separate from those of their vegetable crops in the field (hereafter referred to as field crops). High tunnels also require more labor due to denser plantings, faster crop growth, longer growing seasons, and succession plantings. In addition, because high tunnels require greater financial investment than field crops, farmers are compelled to invest more labor to ensure that this piece of valuable real estate is paying for itself on the farm. One farmer's response to the question about challenges was representative of this:

I'd like to be a better manager where we could get more out of the effort we put forward. It seems like we don't get quite as much return as we should. But that's due to management, I feel (personal interview, 4 Oct. 2016).

Other farmers noted a loss of revenue because they could not keep up with the labor required to maintain their high tunnel crops, which included weeding, planting, harvesting, and scouting for pests and diseases. Many of the farmers described situations in which they felt problems with diseases or pests were discovered too late to save a crop, meaning that valuable high tunnel space and investment in the crop were lost because they were not able to provide the necessary time and attention to address problems soon enough. The research team noted that this is likely a common problem for specialty crop farmers in general. However, because of the higher investment in high tunnel crops, it was experienced more acutely. The challenge of keeping up with the high tunnels in addition to other aspects of the farm or nonfarm work was described by all farmers we interviewed.

Our research led to an explanation of the types of labor-related issues involved in high tunnel production and identified a common perception among the interviewed farmers that the greatest barrier to high-capacity management is the required investment of sufficient time and labor in these high tunnels. Because producers may be integrating high tunnel production into farming operations that are likely already labor- and management-intensive, it is not surprising that management and labor-related issues are some of the most significant barriers to successful implementation. In a study performed in Michigan, researchers found that farmers who earned higher returns from their high tunnels had invested an average of $3 \mathrm{~h}$ more per month than those who earned lower wages, with all else being equal. They also found that during the spring and fall seasons, those who earned higher wages spent an average of $10 \mathrm{~h}$ more than the others, thereby indicating the importance of strategic labor investment for successful high tunnel management (Waldman et al., 2012). Therefore, our research was able to provide a better understanding of why labor was identified as a main limiting factor for expanding high tunnel production in a previous survey (Knewtson et al., 2010).

COMPLEXITY OF HIGH TUNNEL MANAGEMENT. Farmers emphasized that high tunnel management is more complex than managing crops grown in the field. The research team noted that farmers using high tunnels often grow many types of crops, and there is much more variation in growing conditions compared with the field; therefore, the rate of crop development is changing. In addition, farmers often undertake multiple plantings, and these are squeezed into a small space; therefore, there is less flexibility in terms of the planting layout. Farmers said that the added complexity of the timing of planting and harvesting are limiting factors because the time required for crops to mature in the high tunnel has not been established and can vary from year to year depending on weather conditions. For instance, one farmer explained:

I think the biggest challenge is figuring it out yourself. The timing on everything. Knowing when it's hotter in there than it is outside. It's like figuring that part out has been the biggest challenge, I think (personal interview, 8 June 2017).

Another farmer also described the complexity of crop scheduling when faced with rapidly changing environmental conditions in the fall and overlapping summer and fall crops:

Definitely a lot more management... days are totally different, right, so you go from the summer when everything is growing overnight and it's ready to just...you have to figure out your mindset and change the way this is going to spread out and what successional planning do you need to look at because a 30day radish is now a 45-50- to 60-day [radish] depending on when you plant it. You know all these things change, so that's definitely a... always a learning curve. And at the same time, when you're trying to establish this stuff, you're also trying to bring everything in from the [field] crops. We've got some of those issues now where we're just too busy doing other stuff and we should be concentrating on these [high tunnel crops] (personal interview, 27 Oct. 2016).

The farmer who provided the previous quote explained how vegetable crops planted in high tunnels vary greatly during the time required to reach the harvest stage, thus making production planning and management more complex than field production. His comment reflects the responses to the survey conducted by the research team. This survey indicated that farmers requested more research and information regarding the timing of 
Table 1. Farmer-identified challenges and opportunities with high tunnel production and recommendations for education, research, and policy to address the challenges and increase the realization of opportunities.

\begin{tabular}{ll}
\hline Challenges & Recommendations \\
\hline $\begin{array}{l}\text { Managing time and labor requirements } \\
\text { Separate planting and harvest schedules for high tunnel } \\
\text { and field production }\end{array}$ & $\begin{array}{c}\text { Education/training } \\
\text { Efficiency }\end{array}$ \\
$\begin{array}{l}\text { Denser plantings, faster-growing crops (in some seasons), } \\
\text { longer growing seasons, and succession plantings }\end{array}$ & Automation \\
Lost revenue is common due to inadequate labor to & Project management, labor forecasting \\
maintain high tunnel crops & \\
$\begin{array}{l}\text { Greater financial investment heightens the cost of crop } \\
\text { failures due to inadequate labor investment }\end{array}$ & Crop development in high tunnels; critical periods for focusing \\
& attention on the crop \\
& Enterprise budgeting \\
& Risk analysis \\
& Research and development \\
& Time and motion studies \\
& Labor-reducing technology, including mechanization \\
Complexity of high tunnel management & Efficient pest scouting \\
Integrating high tunnels into the existing farm business & Education/training \\
Managing the environment (e.g., opening/closing vents; & Whole farm planning \\
Crop environmental requirements and critical action thresholds
\end{tabular}

Recordkeeping and use of records to improve practices

Scheduling planting and harvesting under less predictable conditions and without well-established guidelines

Balancing high tunnel production with market demand

Coordinating planting and harvesting in a year-round growing cycle when two crops may need to occupy the same space for a time (i.e., fall crops must be planted when summer fruiting crops are still in the harvest stage, etc.)

Managing soil fertility and disease in an intensive growing environment

Higher yield per acre and longer production season mean greater demand for nutrients in soil

Limited crop diversity

Lack of winter markets, poor markets

Monthly markets are not frequent enough when produce can be harvested every 2 or 3 weeks

Customers are not aware that produce is available

Developing markets; accessing alternative and secondary markets Research and development

Optimization of crops across space and time in high tunnel production

Postharvest storage and processing options that permit longer marketing windows

Characterization, prediction, and efficient optimization of environmental conditions inside structures

Crop scheduling and prediction of yield timing and quantity

Education/training

Monitoring for and diagnosing plant problems, including nutritional disorders and abiotic and biotic diseases

Soil fertility monitoring and management

Irrigation and fertigation

Integrated disease management

Research and development

Crop and production system-specific (e.g., organic, conventional) soil fertility, crop mineral nutrition, irrigation/fertigation, and integrated disease management

On-farm plant health diagnostic technology/tools and monitoring protocols

Soil health characterization and enhancement in high tunnels

Education/training

Enterprise planning

Marketing options, strategies for developing markets

Community food systems

Postharvest storage

(Continued on next page) 
Table 1. (Continued) Farmer-identified challenges and opportunities with high tunnel production and recommendations for education, research, and policy to address the challenges and increase the realization of opportunities.

\section{Challenges}

\section{Recommendations}

Research and development

Community food systems, including farm-to-school and winter farmers' markets

Value-added and processing options for winter-harvested crops Policy

Increase the investment in farmers' market to increase the number and frequency of winter farmers' markets, thereby improving the return on investment in the high tunnel initiative cost-share

\section{Opportunities}

Recommendations

Higher yield, better quality, and longer shelf life

Education/training

Crop-specific yield, quality, and shelf life improvements for high tunnel compared with field production

Identifying and communicating with customers willing to pay a higher price for quality and shelf life

Research and development

Documentation and explanation of yield, quality, and shelf life differences

Life cycle analysis of high tunnel vs field production

Standardization of yield measurements that include time, space, quantity, and quality

Income source during the off-season

Education/training

Whole farm planning

Enterprise budgeting

Opportunity cost analysis

Research and development

Whole farm financial characterization

Human and societal impacts of year-round vs seasonal farming

Premium price for early products and attracting customers early during the season

Education/training

Pricing trends and strategies

Optimizing crop scheduling by analyzing weekly yield and cash flow Customer loyalty

Research and development

Consumer behavior at farmers' markets

Determinants of success for directly marketing produce

Complementary crops and marketing

Education/training

Crop-specific production information

Consumer trends, food trends

Marketing methods to increase sales per customer

Research and development

Consumer segments and produce purchasing habits

New crops for high tunnels planting and harvesting for high tunnel production.

Farmers also said they struggled with the increased management complexity of high tunnels because of the challenge of balancing the quantity of high tunnel production with market demand. Farmers described struggling with the complexity of scheduling crops so they would be ready when their customers wanted them. The following quote describes the challenge of balancing the management of high tunnel crops and field crops and the management complexity of direct marketing, particularly because markets can fluctuate unpredictably.

There's definitely a lot, there's a buge balance and ebb and flow between marketing and production. It's because sometimes you hit and sometimes you just miss, and you've got this [stuff] out there that doesn't mean anything. It is absolutely hard [to strike that balance]. And then sometimes, like this summer with the [theme] menus, they just, they were alright but they weren't gangbusters, like the menu didn't hit. So, whatever product lineup that was in those menus was going to be my bulk product, it didn't hit, because customers didn't want it. Well, that's not my fault, it's not the chef's fault, it's just what happened. So, how do you judge all of that... I'd love to know. It's hard (personal interview, 27 Oct. 2016).

The research team posited that this complexity is increased because there are key times during winter when market demand is likely to be high, such as during the holidays when production may be low, or when production is high, during the early spring, but farmers' markets have not started yet and winter 
markets may be limited or nonexistent. The research team also notes that all fresh produce farmers deal with scheduling crop timing and volume to meet market demand. However, this task may be complex for high tunnel production because planting and harvesting schedules are less well-established in these systems. Farmers also pointed out that they invest more in their high tunnel production; therefore, the financial consequences of marketing failures are greater. Moreover, estimating the production of both field crops and high tunnel products for direct markets increases the complexity of this balancing act.

Our interviews showed that the difficulty dealing with complexity was partly due to the lack of experience with this type of production; however, the complexity itself derived partly from the high diversity of crops grown by some farmers. Out of the 20 farms we visited, 12 of them grew more than 6 crops during a given year in their high tunnels, and half of these 12 grew more than 10 crops per year. The farmers we visited typically planted a summer fruiting crop such as tomato (Solanum lycoperiscum) or bell pepper (Capsicum annum) early during the spring, and then a mix of winter greens such as lettuce (Lactuca sativa), kale (Brassica oleracea var. acephala), salad mix, spinach (Spinacia oleracea), mustard greens (Brassica juncea), and sometimes root vegetables such as carrot (Daucus carota), radish (Raphanus sativus), and beet (Beta vulgaris) during the summer that were harvested through the fall and into winter. A subset of the farmers (6 of the 20) only grew summer fruiting crops, mostly tomato. Most of the farmers were still experimenting to determine which crops grew well in their high tunnels; therefore, their crop rotations had changed over time and were not the same every year. For example, they may have tried fruiting crops such as eggplant (Solanum melongena), cucumber (Cucumis satious), bell pepper, squash (Cucurbita pepo), and tomato before settling on tomato, or they may have tried rotating between tomato and a crop such as bell pepper every other year.

Farmers explained that the demands on labor and management derived from the intensive cropping, structure management, and overlap with other on- and off-farm responsibilities. Farmers' responses to our interview questions suggested that part of this management challenge is related to the lack of collective knowledge and farming experience with the unique growth patterns of crops in high tunnels. For example, farmers described their struggles with needing to plant fall crops when summer fruiting crops were still in their full harvest stage, or their struggles with winter crops still being harvested when it was time to plant summer crops during the early spring. For farmers who were also juggling livestock, commodity grain crops, vegetable crops grown in the field, and off-farm employment, the difficulty of managing this complexity was heightened. To our knowledge, the management complexity described here has not been identified by previous high tunnel research.

MANAging SOIL FERTILITY AND DISEASES IN AN INTENSIVE GROWING ENVIRONMENT. High tunnels are more intensive growing environments because high-density plantings and limited uncropped space (alleyways) are common; therefore, farmers must make the most of the protected space. Because high tunnel production involves more dense plantings, longer growing periods for many individual crops, and, in some cases, two or three different crops in the same soil over the course of 1 year, it is more intensive. These management tendencies combined with a longer growing season lead to greater demands on soil nutrient supplies. Consequently, producers found it more challenging to manage soil fertility and crop nutrition during the longterm. The intensity of high tunnel production is accentuated by the higher financial investment farmers make in their high tunnel compared with their field crops. This creates the incentive to produce crops very intensively in the high tunnel, which can exacerbate soil fertility management issues. One farmer explained the following:

Challenges are, basically, you have the output of an acre of stuff that you're pulling it out of 2500 square feet or whatever you're growing in. So, yeah. I mean disease management and fertility is a lot bigger issue inside than what it is outside, I would say for us (personal interview, 8 June 2017).

In response to a follow-up question about the aforementioned farmer's comment that soil fertility is more difficult to manage in the high tunnel than in the fields, the farmer explained the pressure to pack in the crops, thereby maximizing production in the high tunnel by planting crops much more densely than they are planted in the field (personal interview, 8 June 2017). Consequently, many of the farmers we visited were experiencing more problems with soil fertility management.

In addition to the tendency to intensify production, there was an incentive to grow crops in the high tunnel year after year that would realize the premium price to maximize production potential and the return on investment in the high tunnel. A subset of four out of the 20 farmers we interviewed tended to plant the same one or two crops year after year-typically tomato or another summer fruiting crop such as bell pepper-because they grow well in high tunnels and realize the premium price. This limited crop diversity combined with the intensity of the small growing environment seemed to increase pest and disease pressure, and it exacerbated soil fertility and crop nutrition management challenges. One of the farmers using this approach explained the new experience of an increase in pest and disease pressures in the high tunnels:

Last year, I planted them way too close together, trying to cram more in there, and they got diseased at the end of the year and they shut down. I still put tomatoes back in this year. I probably should have cleaned them out and let them grow something else all year (personal interview, 29 June 2017).

This subset of farmers who were using similar production practices and focusing exclusively on one or two high-value crops were all experiencing significant disease pressures, which in several cases resulted in crop failure. One of these farmers was even shifting to growing the high tunnel crops in pots instead of the soil to address these issues. There was also a perception among growers that the overall production benefit of high tunnels may be decreasing over time 
because of these problems. Researchers have pointed to the need to address long-term soil quality management for high tunnels because of the longer and more intensive cultivation in these structures (Knewtson et al., 2010b; Montri and Biernbaum, 2009; Rudisill et al., 2015).

LACK OF WINTER MARKETS AND POOR MARKETS. Farmers reported a lack of winter or off-season markets and the limited frequency of existing winter markets as important barriers to maximizing the season extension potential of their high tunnels. Several of the more rurally located farmers explained that the lack of off-season markets was one reason why they did not invest time and labor in their high tunnel production; for them, this was not financially worthwhile. For example, one farmer mentioned no longer growing radish or lettuce in the high tunnel during the fall and early spring. When asked why not, and whether there was a winter market in the area, the farmer responded with the following:

Farmer: Yeah, but I'm tired by then. It's once a month. So, how are you going to, I mean, okay the radishes are ready this week and the market is not for 3 weeks. Now what do we do? That don't work.

\section{$i t$ ? \\ Interviewer: So, it's just not worth}

Farmer: No, it's only once a month and okay go up there and sell $\$ 100$ worth of stuff. Is it really worth it? Why do that? (personal interview, 13 June 2017).

Other farmers extended production into late fall and winter, but they said that their success was limited by the small size or infrequency of the winter markets in their areas. For example, a farmer who markets products through a winter community-supported agriculture (CSA) program and a food service buyer explained the problem with a winter market that only operates once per month:

The drawback to our winter market here is that it's only once a month and, depending on the season, we can be harvesting two or three times a month depending on what the temperatures are. We don't have a lot of good outlets in the winter season yet so we can produce it, but the challenge is the market and also that it's, it seems to be one or the other, that people don't really have it on their radar that they can get fresh greens in the middle of winter, and also then there are some people who do bave it on their radar, but we can't produce enough to meet their needs because the growing is so much slower. I mean, this time of year [early fall] I can cut 3 lb of greens out of a couple square feet and then next week I can cut it again. So, there's some challenges with it (personal interview, 18 Nov. 2016).

Despite the farmer's ability to successfully produce year-round in the high tunnels, it was explained that the winter production could only be increased if the local winter farmers' market was open more than once per month. This finding connects the importance of market availability to labor-related research findings. Specifically, one previous study found that maximizing labor in high tunnels during the spring and fall seasons resulted in the highest effective wages (Waldman et al., 2012). Our findings suggested that one reason for this difference in profitability was the availability of off-season markets. In contrast to the issues of labor and soil fertility management, which have been documented in other discussions about high tunnels (Conner et al., 2010; Knewtson et al., 2010; Waldman et al., 2012), the lack of winter markets has not been wellresearched. Furthermore, Waldman et al. (2012) also reported that this was an issue for some farmers. The only study that focused on how markets shape high tunnel usage found that the number of NRCS-funded high tunnels per county increased in relation to a cluster of market factors, including high direct-to-consumer sales, good access to grocery stores, high median household income, metropolitan counties with more than 250,000 people, and adjacent urban counties with fewer than 20,000 people (Foust-Meyer and O'Rourke, 2015). This underscores the importance of the local food system infrastructure when defining the types of production that are viable for a particular farm. Although we found that growers are able to produce in high tunnels year-round, or close to it, distribution remains a key hurdle for the winter season, when most farmers' markets are closed or operate sporadically. Market research is needed to identify whether there is potential for increasing the frequency of existing winter farmers' markets and adding new ones in areas where there are farmers growing yearround with high tunnels but that are lacking winter markets.

\section{Opportunities}

Differentiating PRODUCTS BASED ON HIGHER YIELD, QUALITY, AND SHELF LIFE. Throughout the interviews, farmers emphasized that improvements in quality, yield, and shelf life of their crops were some of the most important benefits of high tunnels. Due to the protected growing environment, crops had higher quality, which translated to higher marketable yield and increased farm income. For example, one farmer said: "It definitely bumped up quality and it bumped up quantity" (personal interview, 19 Oct. 2016). Another farmer commented: "You're protecting the crops from moisture, so the quality is better on whatever you grow. Everything grows better under plastic" (personal interview, 22 June 2017). The ability to continue harvesting for more months of the year also led to yield increases and more marketable products. For instance, one farmer commented that if he grew more vegetables than he currently did, then he would be growing them all in a high tunnel:

I can get $90 \%$ to $95 \%$ number one tomatoes out of there. I can't do that in the field. It's that quality difference, and then you can just control everything. [It's more intensive management], but it's worth it (personal interview, 13 June 2017).

The higher quality of high tunnel produce also allowed farmers to compete with large grocers with whom they could never compete based on price alone. One farmer explained how this worked with strawberries (Fragaria $\times$ ananassa):

We've got to compete with Kroger. We've got to compete with Meijer. We've got to compete with Walmart. The only way that you can do that, you can't do it on price. You've got to do it on quality... That's how you play their game. 
When we were raising strawberries early on, as soon as our local crop would start to get ready, Kroger would drop their price. They'd be 3 or 4 dollars, and then as soon as the local stuff comes on, they would drop them down to 99 cents, which is at that ... back in the 90s, that's the game they played. They knew that. I had a lady customer come to me some time and say I can go to Kroger and buy berries for 99 cents a pound, why should I be here paying $\$ 2$ a pound for you to pick them. I said you can go buy that strawberry, but it's going to bave a white top, it's not going to have any flavor, it was picked and shipped here from California, and it's been on a truck (personal interview, 22 June 2017).

As this farmer explained, the higher quality of the high tunnel products was an important attribute that allowed farmers to charge higher prices for their products. Another farmer also described how high tunnels have supported the business by improving the quality of crops, which is important for marketing products at a farmers' market. It was emphasized that customers are willing to pay higher prices for higher-quality products at the local farmers' markets (personal interview, 19 Oct. 2016). In addition to higher quality, farmers noted that crops produced in the high tunnel had a much longer shelf life than field crops. For example, farmers noted how tomatoes grown in the high tunnel did not need to be washed and could last 1 week. In contrast, tomatoes harvested from the field needed washing, started to get spots on them soon after harvest, and did not last as long as those grown under cover. Similar observations were noted for other crops, such as berries [i.e., strawberries and cane berries (Rubus sp.)] and cut flowers. For a small-scale, direct market farm business, a longer shelf life means a greater percentage of the harvest can be sold, which translates to higher farm income.

The ability to differentiate their products based on quality, freshness, taste, or other attributes is important for small-scale farmers to increase their viability and help them compete in a marketplace dominated by large retailers. High tunnels provide a mechanism to produce higher-quality crops and delicate crops that could not be grown otherwise. To our knowledge, these more nuanced implications of the farm-level benefits of using high tunnels have not been explored by other studies.

INCOME SOURCE DURING THE OFF-SEASON. Another important opportunity for farmers using high tunnels was the ability to extend their farm income into the fall, winter, and early spring. One farmer explained how she was able to use the CSA program from May through mid-December, which included a 20 -week summer CSA program and an 8-week fall CSA program that ended just before winter in the middle of December. She noted how high tunnels have made this 8-month CSA program possible:

High tunnels really belped us tremendously reach those direct-toconsumer relationships and get those going in the off, what used to be the off, season. So, this is one of those things that I try to explain. I used to bave an off-season and I don't anymore because we grow year-round. So, it's been a big help for that, I obviously couldn't do that without high tunnels (personal interview, 18 Nov. 2016).

Having almost year-round income allowed several of the farmers to attract and retain great workers who developed a commitment to the farm and became regular rather than seasonal employees. This shift to year-round employees boosted the stability of the farm, supported reciprocal relationships of trust, and led to higher levels of skill and knowledge for their employees. It also meant more stable and attractive terms of employment for their workers.

EARLY PRODUCTS ATTRACT SEASON-LONG CUSTOMERS AND BRING PREMIUM PRICES. Another signature benefit of high tunnels is the opportunity to offer produce ahead of the normal season at local farmers' markets. One farmer said:

It worked great. It was perfect. We started out with the strawberries. That was always our goal, to have strawberries in the high tunnel. And, so, I do a lot of strawberries in the field and those come right at Mother's Day or maybe a week before, and the high tunnels come 2 weeks before that. I can sell strawberries and have established customers for the year. It's like hey, here's the guy who has strawberries. Then, when we're in full season and there's lots of competition, they keep coming back. That part has met my expectation of what the high tunnel has done for us. Being 2 weeks earlier than my competition (personal interview, 4 Oct. 2016).

That farmer emphasized the value of being able to bring crops to market earlier than the typical growing season for farmers who directly market their products to consumers. The value of these early sales went beyond the premium price they received. Farmers are using the early sales to connect with new customers and establish a relationship that potentially lasts all season and develops loyalty. This helps the farmer get a bigger share of the purchases made at their local farmers' market.

Many of the farmers we interviewed grew winter salad greens and root crops that they were able to overwinter and continually harvest during the winter months in their high tunnels. Although these crops would not grow much during the winter months, as long as they were wellestablished before the cold weather and reduced sunlight, farmers could keep them sufficiently protected in the high tunnel, often with low tunnels or minimal heat when temperatures dropped. One farmer described that the winter months were approached as "keeping their cooler stocked," meaning succession planting was used to establish greens and root crops that would grow extremely slowly over the winter; these were gradually harvested in sections so that crops were always available for the market over the winter and into early spring. Another farmer explained: "Obviously, the opportunities are premium prices for early stuff. That's just where it's at. That's what makes it worth it, basically" (personal interview, 8 June 2017). Another farmer explained why early products draw a higher price at the farmers' market and how this boosts the CSA program:

Our first box of tomatoes we delivered May 15 this year, so I want to get mid-May tomatoes. If I can nail May and June tomatoes that's like, that's so much more valuable than October tomatoes. And it's just how it is. Like, I'm even tired of tomatoes [in October] (personal interview, 27 Oct. 2016). 
High tunnels provided farmers with the opportunity to increase their viability by increasing their incomeearning months during the year and to earn a premium price for early products. Consumer research performed in Michigan found that consumers are willing to pay a premium price for early and late produce grown locally, and that they would attend their local farmers' markets both earlier in the spring and later in the fall if fresh produce were available (Conner et al., 2009).

COMPLEMENTARY CROPS AND MARKETING. A related opportunity for farmers was the ability to grow crops that complemented their farm business in important ways. Many farmers who we interviewed used their high tunnels to produce crops that added value to their existing enterprise or enhanced their central focus in ways that increased the viability of their farm business. For example, a farm that focused on cut flowers used their high tunnels to grow varieties that were delicate and vulnerable to wind, rain, and pests in ways that made them impossible to produce in the field. These varieties were an important part of the floral bouquets and other product lines produced by this farm, and they would not have been an option without high tunnels. Likewise, they grew flower varieties in their high tunnels during the fall, winter, and early spring, allowing them to maintain a year-round business. They produced holiday florals and wreaths during the holiday season, and they greatly enhanced their wedding flower business by having products year-round. The way high tunnels were used to create a year-round farm business was described as follows:

They've been fabulous for growing my business. They allowed me to start doing winter market and having income in the winter and not being somewhat impoverished by the time May opened up because, back in those days, the market just ran from MayOctober, 6 months out of the year. Oh my gosh, it's expanded my income so much. It's allowed me to do weddings in November and December and March (personal interview, 19 Oct. 2016).

As another example, a farm that focused on agritourism during the fall season was able to offer customers vineripe tomatoes and fall greens during the holiday season (near Thanksgiving) that complemented the existing business that focused on an apple (Malus $\times$ domestica) orchard, "u-pick" pumpkins (Cucurbita sp.), and other fall crops. Farmers were able to create an additional revenue stream to supplement their agritourism program with a CSA program that occurred through the winter. Because they already had products like apples, apple butter, and cider, having winter greens, root crops, and tomatoes during fall and earlier in the spring made it possible to offer a CSA box that included fresh produce. One farmer who relies on a large CSA program to market most of its products described how high tunnels created the ability to boost the CSA offerings by increasing the diversity of products offered early during the growing season and increasing the overall production intensity because crops have a faster growth cycle in high tunnels. This farmer described how it was possible to increase the farm's CSA membership and the number of months during the year when the CSA program could be offered because of high tunnels (personal interview, 18 Nov. 2016).

\section{Summary and conclusions}

This case study provided an indepth picture of farmers' experiences with integrating high tunnels with their farms. Major production challenges identified by producers included the greater complexity of labor requirements, maintaining soil fertility, and managing diseases in an intensive growing environment. Farmers described these difficulties as being related to the uncertainty of harvesting and planting timeframes, high-density plantings, long production seasons, high yields, and the practice of growing the same highvalue crops (e.g., tomato) with limited or no rotation to other cash or cover crops. Some of these issues are undergoing investigation (Knewtson et al., 2010b; Montri and Biernbaum, 2009; Rudisill et al., 2015), but producers have not identified suitable solutions, and there is clearly a need for additional research and education regarding these topics. Overall, farmers indicated that high tunnel production offers great potential but also requires a considerable investment of time and labor to be successful. In the words of one farmer we interviewed, "you get out what you put into it" (Bruce et al.,
2018). The implication is that farmers who make high tunnel production an important focus of their operations may achieve greater return on their investment than those who add high tunnels to an existing operation but lack the substantial time and labor required to manage them.

These issues could be partially addressed by providing more robust information to farmers who are considering getting or currently have high tunnels and raising awareness among farm advisors (e.g., extension and NRCS staff) about the importance of these issues. For example, education programs that teach efficient and effective crop planning and scheduling, soil fertility and disease management, labor requirements and management, and options for automation would prepare growers with a better idea of how to manage high tunnel production. Research should be performed to develop an improved understanding, recommendations, and planning tools for all of these topics so that it will be easier for farmers to manage the complexity of and reduce labor requirements for high tunnels. Additional suggestions regarding education and research are included in Table 1.

Increasing the sophistication of high tunnel structures is another means of addressing management issues. Automated roll-up sides and automated ventilation systems will likely reduce the time and labor involved in managing high tunnels. Moveable high tunnel systems that use three distinct production plots will enable growers to increase their production and crop diversity, incorporate a cover crop, expose the soil to heavy rains that flush the soil to reduce mineral build-up, and expose the soil to freezing temperatures that may reduce pest pressures. These systems can potentially improve the management requirements for increasing soil fertility and potentially decrease disease pressures that accumulate in intensively managed high tunnel systems (Appropriate Technology for Rural Areas, n.d.; Byczynski, 2014; Coleman, 2009). Moveable high tunnel structures are still being developed and improved, and some can be difficult to move and are less stable (Bruce et al., 2018). Research is needed to continue improving and developing moveable high tunnel structural designs and to improve moveable high tunnel crop rotation 
and management systems. Growers will need to evaluate the cost of these options in relation to the benefits to their operations.

Benefits that farmers described included improvements in crop yields, crop quality, and longer shelf life, which helped them boost their farm income and viability. These benefits reported by farmers coincided with the widely reported results of protecting crops from cold, wind, and rain, as well as some weeds and pests (Belasco et al., 2013; Lamont, 2009; Orzolek, 2013). Farmers related product quality and shelf life to their success with differentiating their products and being able to compete with their peers and large retailers; they often commented on how they were known for good quality and how that helped them at farmers' markets and with direct-to-consumer sales. These opportunities can make a big difference for farms marketing their own products, particularly if they market directly to consumers via farmers' markets, CSA programs, or through farm-totable restaurants, as many of the farmers we interviewed are doing. A related benefit was the opportunity to enhance and grow farm businesses by producing complementary crops that could not be grown without high tunnels, thereby increasing their customer base and customer loyalty by offering products year-round. Our study also indicated the potential for high tunnels to facilitate increased employment for small farms that otherwise might not be able to afford employees or to facilitate the hiring of year-round workers. High tunnels made it possible for some farmers to establish more stable and economically viable businesses with greater growth potential because they were generating enough income to hire workers and further increase their capacity. These benefits and opportunities are summarized in Table 1. Suggestions for education and research to help growers recognize and take full advantage of those opportunities that fit their operations are also provided in Table 1.

The use of in-depth interviews for this project allowed the reporting of specific examples that illustrate the experiences of farmers with high tunnels. These specific examples are valuable for developing an understanding of the issues and how they can be addressed in the best way. Furthermore, these examples combined with the results of surveys and quantitative research will enable more rapid improvements in high tunnel production systems through research, improvements in technology, and education.

\section{Literature cited}

Appropriate Technology Transfer for Rural Areas. n.d. Question of the week: Moveable high tunnels. 26 Nov. 2018. <https://attra.ncat.org/calendar/ question.php/what-information-canyou-give-me-on-movable-high-tunnels $>$.

Belasco, E., S. Galinato, T. Marsh, C. Miles, and R. Wallace. 2013. High tunnels are my crop insurance: An assessment of risk management tools for small-scale specialty crop producers. Agr. Resour. Econ. Rev. 42:403-418.

Bruce, A.B., J.R. Farmer, E.T. Maynard, and J.D. Valliant. 2017. Assessing the impact of the EQIP High Tunnel Initiative. J. Agr. Food Syst. Community Dev. 7:159-180.

Bruce, A.B., E.T. Maynard, J.R. Farmer, and J. Carpenter. 2018. Indiana high tunnel handbook. 5 Mar. 2019. <https:// edustore.purdue.edu/item.asp? Item _ Number $=$ HO-296-W $>$.

Byczynski, L. 2014. The hoophouse handbook e-book. 2nd ed. Perfect Paperback, Fairplain Publ., Lawrence KS.

Carey, E.E., L. Jett, W.J. Lamont, T.T. Nennich, M.D. Orzolek, and K.A. Williams. 2009. Horticultural crop production in high tunnels in the United States: A snapshot. HortTechnology 19:37-43.

Coleman, E. 2009. The winter harvest handbook: Year-round vegetable production using deep-organic techniques and unheated greenhouses. Chelsea Green Publ., White River Junction, VT.

Conner, D.S., A.D. Montri, D.N. Montri, and M.W. Hamm. 2009. Consumer demand for local produce at extended season farmers' markets: Guiding farmer marketing strategies. Renew. Agr. Food Syst. 24:251-259.

Conner, D.S., K.B. Waldman, A.D. Montri, M.W. Hamm, and J.A. Biernbaum. 2010. Hoophouse contributions to economic viability: Nine Michigan case studies. HortTechnology 20:877-884.

Creswell, J.W. and C.N. Poth. 2017. Qualitative inquiry and research design: Choosing among five approaches. 5 th ed. Sage Publ., Thousand Oaks, CA.
Foust-Meyer, N. and M.E. O'Rourke. 2015. High tunnels for local food systems: Subsidies, equity, and profitability. J. Agr. Food Syst. Community Dev. 5:27-38.

Knewtson, S.J.B., E.E. Carey, and M.B. Kirkham. 2010. Management practices of growers using high tunnels in the central Great Plains of the United States. HortTechnology 20:639-645.

Knewtson, S.J.B., R. Janke, M.B. Kirkham, K.A. Williams, and E.E. Carey. 2010b. Trends in soil quality under high tunnels. HortScience 45:1534-1538.

Lamont, W.J. 2009. Overview of the use of high tunnels worldwide. HortTechnology 19:25-29.

Miles, M.B. and M. Huberman. 1994. Qualitative data analysis. 2nd ed. Sage Publ., Thousand Oaks, CA.

Montri, A.D. and J.A. Biernbaum. 2009. Management of the soil environment in high tunnels. HortTechnology 19:34-36.

National Sustainable Agriculture Coalition. 2014. Seasonal high tunnels support conservation and new farmers. NSAC Blog 27 June 2014. 2 Oct. 2018. <http://sustainableagriculture.net/ blog/high-tunnel-update $/>$.

Natural Resources Conservation Service. 2015. FY 2015 EQIP Seasonal High Tunnel Initiative. 4 June 2018. <http:// www.nrcs.usda.gov/wps/portal/nrcs/ detail/national/programs/financial/ eqip $/$ ?cid $=$ nrcs142p2_044210 $>$.

Orzolek, M.D. 2013. Increasing economic returns to high tunnels with specialty crops. Acta Hort. 987:83-88.

Rudisill, M.A., B.P. Bordelon, R.F. Turco, and L.A. Hoagland. 2015. Sustaining soil quality in intensively managed high tunnel vegetable production systems: A role for green manures and chicken litter. HortScience 50:461-468.

Starmer, E. 2014. High tunnel initiative brings local foods to Detroit. U.S. Dept. of Agriculture Blog 20 Feb. 2014. 26 Nov. 2018. <http://blogs.usda.gov/2014/02/ 20/high-tunnel-initiative-brings-localfoods-to-detroit/\#more-50193>.

U.S. Department of Agriculture. n.d. Know your farmer, Know your food compass. 8 Sept. 2018. <http://www.usda.gov/ documents/KYFCompass.pdf $>$.

Waldman, K.B., D.S. Conner, J.A. Biernbaum, M.W. Hamm, and A.D. Montri. 2012. Determinants of hoophouse profitability: A case study of 12 novice Michigan farmers. HortTechnology 22:215-223. 